\title{
Factors That Affect Motivation Among Adult Learners
}

Thomas M. Green, (Email: tgreen@nu.edu), National University Chandrika M. Kelso, (Email: ckelso@nu.edu), National University

\begin{abstract}
Motivation is an internal force that energizes the individual for action and determines the direction of that action. Antecedent conditions (e.g. attitudes toward the subject, concern for academic excellence), and methodological or course design conditions (classroom variety, instructional activities, direct feedback) are variables that influence student motivation. This research presents the results of a survey $(N=563)$ that examined the influence of personal, teacher behavior, and institutional-structural factors on adult students at the second largest private university in California. The results indicate that teacher behaviors are among those rated by students as having the most influence on their motivation to succeed.
\end{abstract}

\section{INTRODUCTION}

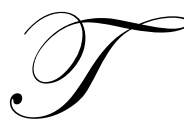

he face(s) of higher education has (have) changed dramatically in the past 30 years. In 1970, $11 \%$ of fulltime students were 25 years of age and older; by 1999, that figure had nearly doubled to $20 \%$. This shift is even more dramatic among females: from 1970 to 1999, the percentage of females pursuing postsecondary education who were age 25 and older grew from $7 \%$ to over $21 \%$; for males, the percentage increased from $13 \%$ to $19 \%$. Females also accounted for the majority of postsecondary students in 1999 (54\%), up from $40 \%$ in 1970 (“Degree-Granting Postsecondary," 2001).

The trends are similar for part-time students, who historically are older than fulltime students. In 1970, 63\% of part-time students were 25 years and older; in 1999, that figure was $67 \%$. While the percentage of male part-time students age 25 and over declined slightly during this period (from $67 \%$ to 66\%), the percentage of female students increased from 58\% to $68 \%$. Among all part-time students, females also moved from a minority in 1970 (44\%) to a majority by 1999 (59\%). Projections for 2010 suggest that the percentage of all postsecondary students accounted for by females will continue to increase ("Degree-Granting Postsecondary," 2001).

While these trends have been emerging for the past 30 years, many policies and practices in higher education are still designed for 18-22 year olds (Mancuso, 2001). It is clear that "best practices" need to be developed that respond to the adult learner.

Adult learners can be defined as persons who are no longer dependent on parents or guardians, have assumed major life responsibilities (e.g. work, family, community), whose self-identities are beyond those of a fulltime student (Mancuso, 2001; "Serving Adult Learners in Higher Education," 1999), and who operate independently in society (Mancuso, 2001). Research on adult learners suggest some important differences from their younger counterparts, including prior knowledge and experience (Mancuso, 2001; Reid, 2000; "Serving Adult Learners," 1999; Merriam \& Caffarella, 1991; Erickson, 1984; Cross, 1981; Kidd, 1973), self-directedness (Reid, 2000; Brookfield, 1986; Knowles, 1980; Tough, 1979; Tough, 1966), a greater capacity for critical reflection (Reid, 2000), and more active engagement in the learning experience (Mancuso, 2001; Reid, 2000; "Serving Adult Learners," 1999; Kolb, 1984; Cross, 1981; Knowles, 1980; Ausubel, Novak, \& Hanesian, 1978). 
Adult students differ from younger students in another other important aspect, what Sheehy (1976) described as "marker experiences" (e.g. marriage, divorce, getting a job, changing careers, etc.). Marker experiences may provide stronger motivation to learn specific skills or knowledge than younger students.

Most educators and psychologists describe motivation as those processes that can arouse and bring about behavior, give direction and purpose to behavior, allow behavior to continue, and lead to choosing or preferring a particular behavior (Wlodkowski, 1991). Motivation is an internal force that leads to action and determines the direction of that action (Hunter, 1967; Russsell, 1971).

Unless learners are adequately motivated, they will not perform effectively, nor will they find learning rewarding or satisfying (Mouton \& Blake, 1984). There are two types of motivation. Intrinsic motivation results from the personal desire to fulfill one's own needs; the rewards are internal (i.e. personal satisfaction) (Andrews, Houston, \& Bryant, 1981; Bellon, Bellon, \& Handler, 1977; Sheehy, 1976; Russell, 1971). Extrinsic motivation depends on external rewards, which can take the form of praise, privileges, or tangible objects (Erickson, 1984; Bellon, Bellon, \& Handler, 1977; Brophy, 1972).

One who teaches adults must understand what motivates his/her students (Andrews, Houston, \& Bryant, 1981). Research on motivating adult learners has generally involved three approaches (Rinne, 1998). One focus has been on learner characteristics (achievement motivation, self-worth, competence) (see Ames and Ames, 1984); a second on teacher characteristics and instructional methodology (see Rinne, 1998 for summary of literature); a third on characteristics of lesson content (see Rinne, 1998). To understand how and why a person invests energy to obtaining educational goals, it is important to acknowledge that school environment and teaching practices are critical sources for goal definition and attainment (Maehr, 1998; Christophel \& Gorham, 1995; Frymier, 1993; Gorham \& Christophel, 1992; Renchler, 1992; Christophel, 1990).

Gorham and Christophel (1992) developed a model similar to the one described by Rinne (1998) is a study designed to assess students' perceptions of the factors that motivated them to succeed in college classes; subsequently, Gorham and Millette (1997) used a similar methodology to compare the perceptions of students and teachers regarding the factors that affect the motivation and demotivation of college students. The authors categorized student and teacher responses to open-ended questions and found three sets of factors: context factors (conditions that students bring to the classroom, such as desire to earn good grades and other internal characteristics); structure/format factors (organization of class material, grading, opportunities to participate), and teacher behavior factors (e.g. sense of humor, interest in students, speaking clearly, enthusiasm).

Context factors emerged as relatively more important to motivation and structure/format factors to demotivation, with teacher behavior contributing equally to motivation and demotivation in terms of the data as a whole. The third and fourth research questions were concerned specifically with how teacher behaviors contribute to motivation and demotivation. Teacher behaviors accounted for $44 \%$ of the overall motivators; teacher immediacy behaviors accounted for $34 \%$ of the overall motivators listed (Gorham \& Christophel, 1992).

\section{METHODOLOGY}

\section{Survey Design}

This research utilized a survey that asked students to rank on a scale of $0-4$ (where $0=$ Not important, $1=\mathrm{A}$ little important, $2=$ Important, $3=$ Very important, and 4=Extremely important) the degree to which 63 factors affected motivation and 60 factors affected demotivation. Motivation factors were defined as those that affect desire and efforts to succeed; demotivation factors were defined as those that negatively affect, or interfere with, desire and efforts to succeed.

The survey instrument used in this research was based on the work of Gorham and Christophel (1992) who examined the factors that undergraduate students perceived as motivating them to do their best in college. The factors identified in Gorham and Christophel's study were transformed into statements to which students could apply the 
rating scheme. Additional factors were gleaned from the literature on motivation, especially that which focused on adult learners.

Three focus groups were held with students at National University. In each group, students were asked to identify personal (intrinsic), teacher behavior, and institutional-structural factors that affected both their desire to succeed (motivation) and interfered with their desire to succeed (demotivation). The factors identified in those focus groups were also included in the survey.

The survey instrument was pilot-tested on two groups of students. Students were asked to identify unclear statements and points of confusion. The final version of the survey instrument incorporated revisions suggested by these two groups.

\section{Setting And Sample}

This research was conducted at National University in July 2003. National University is the second largest private university in the State of California with approximately 17,000 full-time students. The University is headquartered in La Jolla, a suburb of San Diego, but is highly decentralized. The University utilizes satellite campuses, located as far north as Redding and as far south as Chula Vista. Altogether, there are 30 regional academic centers located in three regions: Northern (which includes Redding, Sacramento, Stockton, San Jose, Fresno, and Bakersfield), Southern (Los Angeles and Orange Counties, and San Bernardino), and San Diego County.

National University is an excellent setting for studying the adult learner. For the past 34 years, the University has offered four-week courses that meet two nights per week (and one or two Saturdays per month) from 5:30 to 10:00 p.m. Almost all students work full or part-time. National University is accredited by the Accrediting Commission for Senior Colleges and Universities of the Western Association of Schools and Colleges (WASC), as well as numerous other discipline-specific accreditations.

In July 2003, approximately 10,500 students were enrolled in classes statewide (this research does not include online students). A stratified, proportionate sampling technique was used. First, all classes offered in July 2003 were organized by region, then by the three largest schools (Business and Management, Arts and Sciences, and Education), and finally by undergraduate and graduate levels. Classes were selected for the sample using two criteria: the number of students in each strata (e.g. undergraduate Business students in the Northern region) should be proportional to the total number of students in each strata; and courses within each strata should reflect the diversity of the programs in each school (i.e. the sample of Business courses should include accounting, finance, management, etc.).

Based on enrollment data available in June 2003, a total sample of 1012 was developed (9.6\% of July 2003 enrollments). The sample was comprised of 254 Business students ( $25.1 \%$ of the sample), 483 Education students (47.7\%), and 275 Arts and Sciences students (27.2\%) in 38 different classes. Each class instructor was contacted about the survey and agreed to participate. Each instructor was mailed a set of questionnaires and a standardized instruction sheet for administering the survey. The instructors collected the completed surveys that were returned to the lead researcher for data entry and analysis.

There was significant attrition from the classes that comprised the sample. Of the 1012 students scheduled to take the 38 classes, 823 completed, an attrition rate of $18.7 \%$. Attrition did not significantly alter the proportions in the sample. The greatest part of the attrition rate is accounted for by those students who are enrolled, but for one reason or another, never attend class. A small percentage of students drop the class within the first week. For the purposes of this research, the total number of students who received a survey totaled 823; therefore, the 563 valid surveys used in the analyses represent a response rate of $68.4 \%$. 


\section{RESULTS}

The 563 valid surveys that were returned closely reflect the relative proportions between the three schools in the sample: $26.1 \%$ of the valid returns (excluding those that did not include affiliation with a particular school) were Business students, $51.0 \%$ were Education students, and $22.9 \%$ were Arts and Sciences students. The average age of the survey respondents was 33.9 years (compared to the overall University average of 32 years, 34 for graduate students), two-thirds (66.8\%) were female (compared to 60\% University-wide), and $71.9 \%$ were graduate students (compared to University totals of $72.8 \%$ ).

\section{Motivation Factors}

While the single-most influential factor affecting motivation was "Personal pride in my efforts and success" (3.59 for all respondents), survey respondents indicated that teacher behaviors are more likely to affect their desire and efforts to succeed (motivation) in class than either personal or institutional-structural factors. On a scale of 0-4, the average ranking of the influence of personal factors totaled 3.14; personal factors 2.39; and institutional-structural 2.39 .

Table 1: Factors That Affect Motivation Among Adult Learners

\begin{tabular}{|c|c|c|c|c|c|c|c|c|}
\hline \multirow[t]{2}{*}{ Motivation Factors } & \multicolumn{2}{|c|}{ Total } & \multicolumn{2}{|c|}{ Business } & \multicolumn{2}{|c|}{ Education } & \multicolumn{2}{|c|}{ Arts \& Sciences } \\
\hline & $\mathrm{x}$ & sd & $\mathrm{x}$ & sd & $\mathrm{x}$ & sd & $\mathrm{x}$ & $\mathrm{sd}$ \\
\hline PERSONAL & 2.39 & & 2.41 & & 2.34 & & 2.47 & \\
\hline TEACHER BEHAVIORS & 3.14 & & 3.12 & & 3.16 & & 3.11 & \\
\hline INSTITUTIONAL-STRUCTURAL & 2.39 & & 2.58 & & 2.33 & & 2.45 & \\
\hline Personal pride in efforts and success & 3.59 & .66 & 3.64 & .53 & 3.52 & .75 & 3.72 & .54 \\
\hline Instructors who are competent & 3.55 & .75 & 3.52 & .84 & 3.55 & .77 & 3.56 & .65 \\
\hline $\begin{array}{l}\text { Instructors who speak clearly/clear } \\
\text { explanations }\end{array}$ & 3.48 & .71 & 3.50 & .75 & 3.45 & .74 & 3.56 & .62 \\
\hline Clear expectations & 3.48 & .77 & 3.57 & .75 & 3.48 & .80 & 3.43 & .70 \\
\hline Instructors with common sense & 3.48. & .80 & 3.46 & .84 & 3.46 & .85 & 3.51 & .70 \\
\hline Meaningful/relevant assignments & 3.46 & .71 & 3.48 & .67 & 3.50 & .71 & 3.39 & .69 \\
\hline Instructors who are receptive to questions & 3.45 & .77 & 3.43 & .84 & 3.48 & .78 & 3.42 & .67 \\
\hline $\begin{array}{l}\text { Instructors who have a genuine interest in } \\
\text { students }\end{array}$ & 3.43 & .81 & 3.40 & .91 & 3.49 & .75 & 3.33 & .87 \\
\hline Instructors who are organized & 3.42 & .80 & 3.40 & .83 & 3.42 & .84 & 3.45 & .69 \\
\hline $\begin{array}{l}\text { Instructors who interact/work with } \\
\text { students }\end{array}$ & 3.38 & .80 & 3.35 & .84 & 3.37 & .85 & 3.39 & .71 \\
\hline $\begin{array}{l}\text { Instructors who are passionate about } \\
\text { subject matter }\end{array}$ & 3.36 & .85 & 3.30 & .92 & 3.41 & .85 & 3.32 & .82 \\
\hline $\begin{array}{l}\text { Instructors who know material on a } \\
\text { personal level }\end{array}$ & 3.35 & .82 & 3.13 & .94 & 3.42 & .75 & 3.35 & .83 \\
\hline Instructors who are responsible & 3.32 & .87 & 3.32 & .86 & 3.30 & .88 & 3.34 & .86 \\
\hline $\begin{array}{l}\text { Instructors who work in the same field in } \\
\text { which they are teaching }\end{array}$ & 3.26 & .93 & 3.11 & .96 & 3.28 & .94 & 3.36 & .84 \\
\hline For intellectual gain, knowledge & 3.24 & .92 & 3.35 & .86 & 3.12 & .98 & $3.36 \mathrm{~B}$ & .84 \\
\hline Increased marketability, employability & 3.24 & .98 & 3.35 & .97 & 3.15 & .99 & 3.40 & .88 \\
\hline The quality of the education & 3.23 & .98 & 3.36 & .98 & 3.16 & 1.03 & 3.28 & .85 \\
\hline
\end{tabular}

Table 1 (below) summarizes the rankings for the 15 factors with the highest averages. Three personal factors are included: "Personal pride in my efforts and success"; "For intellectual gain or knowledge"; and "To increase my marketability, employability." The only one of these personal factors that varied significantly between schools was "Personal pride" ( $p=.02)$. Among Business students, 96.7\% ranked personal pride as Very Important or Extremely Important. Similarly, 97.5\% of Arts and Sciences students ranked personal pride as Very Important or Extremely Important, while only $85.2 \%$ of Education students had those rankings. Moreover, $1.1 \%$ of Education students 
indicated that personal pride was Not Important or of Little Importance, while no Business or Arts and Sciences students shared that perception.

Only one institutional-structural factor is included among the 15 most influential factors: "The quality of my education"; the remainder are teacher behavior factors. The quality of education factors ranked $10^{\text {th }}$ among Arts and Sciences students, $15^{\text {th }}$ among Education students, and $17^{\text {th }}$ among Business students, and $17^{\text {th }}$ overall. The results did not vary significantly between schools $(p=.09)$.

Among Business students, there were no significant differences between males and females on any of the most influential factors. Only three motivation factors varied significantly by sex: "To be able to manage my time, or demonstrate that I can manage my time" (average ranking $=1.81, \mathrm{SD}=1.381, p=.049$ ), where females were more likely to rank the factor as Very Important or Extremely Important (35.9\% v. 26.7\% for males) and males were more likely to rank the factor as Not Important or of Little Importance (50.0\% v. 34.6\% for females); "The cost of onbase/off-site courses" (average ranking $=2.41, \mathrm{SD}=1.413, p=.035$ ), where females were more likely to rank the factor as Very Important or Extremely Important $(42.9 \%$ v. $25.3 \%$ for males) and males were more likely to rank the factor as Not Important or of Little Importance (33.4\% v. $29.3 \%$ for females); and "The quality and use of AV materials" (average ranking $=2.16, \mathrm{SD}=1.146, p=.019$ ), where males were more likely to rank the factor as Very Important or Extremely Important (37.9\% v. $31.7 \%$ for males) and females were more likely to rank the factor as Not Important or of Little Importance (26.6\% v. $20.7 \%$ for females).

Table 2: Factors That Affect Demotivation Among Adult Learners

\begin{tabular}{|l|l|l|l|l|l|l|l|l|}
\hline \multirow{2}{*}{ Demotivation Factors } & \multicolumn{2}{|c|}{ Total } & \multicolumn{2}{c|}{ Business } & \multicolumn{2}{c|}{ Education } & \multicolumn{2}{c|}{ Arts \& Sciences } \\
\cline { 2 - 8 } & $\mathrm{X}$ & $\mathrm{sd}$ & $\mathrm{X}$ & $\mathrm{sd}$ & $\mathrm{X}$ & $\mathrm{sd}$ & $\mathrm{X}$ & $\mathrm{sd}$ \\
\hline PERSONAL & 2.07 & & 1.93 & & 2.11 & & 2.03 & \\
\hline TEACHER BEHAVIORS & 2.66 & & 2.62 & & 2.73 & & 2.54 & \\
\hline INSTITUTIONAL-STRUCTURAL & 2.39 & & 2.25 & & 2.45 & & 2.35 & \\
\hline Instructor difficult to understand & 3.00 & 1.19 & 3.01 & 1.13 & 3.01 & 1.23 & 2.93 & 1.19 \\
\hline Unrealistic expectations & 2.98 & 1.23 & 2.93 & 1.23 & 3.09 & 1.21 & 2.78 & 1.25 \\
\hline Instructor disorganized & 2.97 & 1.22 & 2.92 & 1.18 & 3.04 & 1.24 & 2.84 & 1.24 \\
\hline Instructor lack of interest & 2.93 & 1.23 & 2.93 & 1.18 & 3.00 & 1.26 & 2.78 & 1.23 \\
\hline Unfair grading & 2.93 & 1.29 & 2.93 & 1.94 & 3.01 & 1.29 & 2.74 & 1.37 \\
\hline Instructor not receptive to questions & 2.92 & 1.25 & 2.90 & 1.21 & 3.01 & 1.26 & 2.72 & 1.27 \\
\hline Credits that cannot be transferred & 2.89 & 1.36 & 2.95 & 1.26 & 2.79 & 1.47 & 2.93 & 1.30 \\
\hline Instructors with no teaching experience & 2.85 & 1.32 & 2.77 & 1.33 & 2.88 & 1.36 & 2.88 & 1.24 \\
\hline Quality of education & 2.79 & 1.27 & 2.68 & 1.29 & 2.82 & 1.26 & 2.73 & 1.29 \\
\hline Instructors who intimidate & 2.79 & 1.39 & 2.90 & 1.30 & 2.91 & 1.38 & 2.46 & 1.45 \\
\hline Boring concepts & 2.79 & 1.29 & 2.65 & 1.33 & 2.97 & 1.23 & 2.57 & 1.33 \\
\hline Price/quality of books & 2.75 & 1.21 & 2.68 & 1.23 & 2.75 & 1.23 & 2.73 & 1.17 \\
\hline Inflexible instructors & 2.75 & 1.31 & 2.67 & 1.31 & 2.83 & 1.34 & 2.65 & 1.27 \\
\hline Instructors who just lecture & 2.74 & 1.31 & 2.55 & 1.34 & 2.91 & 1.27 & 2.55 & 1.33 \\
\hline Classes that do not matter & 2.73 & 1.36 & 2.39 & 1.42 & 2.95 & 1.29 & 2.55 & 1.38 \\
\hline Lack of feedback from instructor & 2.68 & 1.27 & 2.71 & 1.26 & 2.66 & 1.29 & 2.66 & 1.26 \\
\hline Irrelevant homework & 2.65 & 1.30 & 2.38 & 1.38 & 2.76 & 1.27 & 2.58 & 1.29 \\
\hline Instructor large ego & 2.65 & 1.40 & 2.79 & 1.28 & 2.70 & 1.44 & 2.37 & 1.41 \\
\hline Disorganized courses & 2.61 & 1.34 & 2.42 & 1.38 & 2.67 & 1.34 & 2.58 & 1.34 \\
\hline Bad timing of courses & 2.60 & 1.33 & 2.51 & 1.42 & 2.64 & 1.33 & 2.60 & 1.25 \\
\hline
\end{tabular}

\section{Demotivation Factors}

Teacher behaviors are also influential in demotivating (i.e. negatively affect, or interfere with, desire and efforts to succeed). Having an instructor who is difficult to understand was the strongest demotivating factor for Arts and Sciences and Business students, and the fifth most influential factor among Education students (average ranking 
3.01, 2.93, and 3.01, respectively). The differences in rankings were not significant. Table 2 (below) summarizes the findings on the 15 most influential factors affecting demotivation.

Only one demotivation factor varied significantly by school $(p=.03)$ : "Instructors who intimidate." While $69.0 \%$ of Education students and $64.1 \%$ of Arts and Sciences students ranked this factor as Very Important or Extremely Important, only $53.0 \%$ of Business students had similar responses.

Among Business students, there were no significant differences between males and females on any of the most influential demotivation factors. Only two demotivation factors varied significantly by sex: "Not being successful in classes" (average ranking $=2.10, \mathrm{SD}=1.376, p=.012$ ), where males were more likely to rank the factor as Very Important or Extremely Important $(45.0 \%$ v. $36.9 \%$ for females) and males were also more likely to rank the factor as Not Important or of Little Importance $(40.0 \%$ v. $28.9 \%$ for females) - females were much more likely to consider this factor as Important (34.2\% v. 15.0\% for males); "The cost of on-base/off-site courses" (average ranking $=2.41, \mathrm{SD}=1.413, p=.035)$, where females were more likely to rank the factor as Very Important or Extremely Important ( $42.9 \%$ v. $25.3 \%$ for males) and males were more likely to rank the factor as Not Important or of Little Importance (33.4\% v. $29.3 \%$ for females); and "The quality and use of AV materials" (average ranking $=2.16$, $\mathrm{SD}=1.146, p=.019$ ), where males were more likely to rank the factor as Very Important or Extremely Important (37.9\% v. $31.7 \%$ for males) and females were more likely to rank the factor as Not Important or of Little Importance ( $26.6 \%$ v. $20.7 \%$ for females).

\section{DISCUSSION}

The rankings of motivation and demotivation factors by Business, Education, and Arts and Sciences students are remarkably similar. Among the 45 most influential motivation factors ( 15 for each of the three schools), students in all three schools shared 11 factors; and six factors were shared by two of the three schools. Overall, students from the three schools agreed on $73.3 \%$ of the most influential factors.

Among the 45 most influential demotivation factors, 11 factors were shared by all three schools; five factors were shared by two schools; and only five factors appeared on only one school's list. Overall, students from the three schools agreed on $66.7 \%$ of the most influential factors.

As stated above, only one motivation and one demotivation factor were statistically significant. This finding is surprising only if it is assumed that what characterizes this sample of adult learners is their academic discipline. What these data reflect is that the adult learners in this sample are motivated and demotivated by similar personal, teacher behavior, and institutional-structural factors, and that a chosen academic discipline is not what most affects motivation and demotivation. The implications of this finding are discussed below in the Conclusions section.

There are significant differences between students in Business, Education, and Arts and Sciences. Demographically, Business students are more likely to be male (43.2\%) than Arts and Sciences (31.1\%) or Education (27.9\%) students $(p=.007)$. Business students are slightly older (34.5 years; range $=20-57$ years) than Arts and Sciences (34.0 years; range $=20-59$ years) and Education students (33.8 years; range $=22-61$ years), just missing the cut-off for statistical significance at $p=.056$.

Race/ethnicity also varied significantly by school ( $p=.005)$. Among Education students, $31.1 \%$ were White, compared to $10.5 \%$ of the Arts and Sciences and $11.4 \%$ of the Business students; overall, $58.7 \%$ of White students are enrolled in Education. The greatest percentage of Black students, 37.0\%, were enrolled in Business, accounting for $3.2 \%$ of Business students (v. 2.8\% of Education and 2.6\% of Arts and Sciences students). Hispanic students were more likely to be in Education (43.9\% of all Hispanic students, $8.1 \%$ of Education students) than Arts and Sciences (29.6\% of all Hispanic students, 5.4\% of Arts and Sciences students) or Business (26.5\% of all Hispanic students, $4.9 \%$ of Business students).

The differences $(p=.000)$ between the percentage of undergraduate and graduate students is not surprising: the School of Education has no undergraduate programs (though some undergraduate students identified themselves 
as Education students). Ninety-seven percent of the Education students in the sample are enrolled in graduate programs, compared to $53.3 \%$ of Business and $38.0 \%$ of Arts and Sciences students.

There were also several factors that varied significantly between schools. While these factors are not among those with the highest average rating, some are interesting and are and described in Table 3.

Table 3: Additional Significant Factors Rated Important Or Very Important (Percentage)

\begin{tabular}{|l|c|c|c|c|}
\hline Motivation Factors & Business & Education & Arts And Sciences & Total \\
\hline Career change $(p=.002)$ & $66.9 \%$ & $71.3 \%$ & $62.5 \%$ & $65.6 \%$ \\
\hline Fear of failure $(p=.015)$ & $45.3 \%$ & $33.9 \%$ & $20.3 \%$ & $33.8 \%$ \\
\hline Personal challenge $(p=.016)$ & $70.1 \%$ & $68.3 \%$ & $71.1 \%$ & $69.4 \%$ \\
\hline To please teacher $(p=.048)$ & $12.9 \%$ & $14.5 \%$ & $6.7 \%$ & $12.3 \%$ \\
\hline Technology in classroom $(p=.012)$ & $38.8 \%$ & $28.7 \%$ & $31.8 \%$ & $32.4 \%$ \\
\hline Caters to adults $(p=.003)$ & $67.7 \%$ & $56.0 \%$ & $70.4 \%$ & $62.3 \%$ \\
\hline Reputation of University $(p=.051)$ & $60.6 \%$ & $49.1 \%$ & $62.0 \%$ & $55.1 \%$ \\
\hline Instructors who disclose $(p=.022)$ & $37.2 \%$ & $51.6 \%$ & $42.6 \%$ & $45.9 \%$ \\
\hline Demotivation Factors & & & & \\
\hline Amount of coursework $(p=.042)$ & $49.6 \%$ & $48.7 \%$ & $35.0 \%$ & $45.9 \%$ \\
\hline Length of degree program $(p=.000)$ & $46.0 \%$ & $52.2 \%$ & $34.2 \%$ & $46.5 \%$ \\
\hline Taking classes that don't matter $(p=.006)$ & $56.2 \%$ & $69.9 \%$ & $53.0 \%$ & $62.5 \%$ \\
\hline
\end{tabular}

\section{CONCLUSIONS}

Motivation is a critical variable in student learning. For many adult students, strong motivation is required to attend (or return to) a university after 10 or 20 years of work, starting and raising a family, and other interests and obligations. It is not uncommon to have in an evening class a single parent with children at home and a full-time job; what it takes for that person to be successful appears, on its face, to be very different from an 18 year old fresh out of high school.

As teachers we often assume that students come to class with internally derived motivation and that we play, at most, a small role in nurturing that motivation. While personal pride in one's success is the most powerful source of motivation, this research suggests that teachers play a much more critical role in motivating students to be successful. Students who have 10 or 20 years of work experience may be more likely to expect instructors who are competent, who are working in the field in which they are teaching, who genuinely care about their students, and who manage the class efficiently.

There may be another level to the influence of teacher behaviors and how they affect student motivation. Beyond students expecting that instructors have certain qualities, they may actually depend on those qualities to allay self-doubt or to provide that extra boost to overcome stress and the challenges of returning to school after many years.

While demotivation factors were not ranked as important as motivation factors, the concept of demotivation (even with the attendant definition in the survey) is less intuitive than motivation and may account for the lower rankings. That said, this research suggests that teacher behaviors are also instrumental in "turning students off" to their coursework and learning in general. In many instances, those factors that demotivate students are the opposite of the factors that motivate. Instructors who are difficult to understand (either as the result of a strong accent or an inability to articulate concepts), who are disorganized, inexperienced, unfair, and disinterested are likely to interfere with students' desire to succeed in class. A more thorough analysis of the motivation-demotivation continuum will be included in future research.

It may be reasonable to conclude that the motivation demonstrated by adult learners to attend or return to college may be somewhat fragile or tenuous. If an instructor places significant barriers to student success, student 
desire to succeed may suffer. This inference could be tested by surveying or interviewing students who drop classes, take breaks from their course schedule, take longer to complete their degree, or who drop-out completely.

The results of this survey reveal that teachers play a very important role in the success of their students. By recognizing and addressing those personal and pedagogical behaviors that help to stimulate the internal desire to succeed, teachers can provide far more to their students than specific course content. There is very clearly a dynamic between a teacher and his or her students, and understanding how that relationship affects such a fundamental antecedent to learning as motivation may be one of the most important aspects of teaching adult learners.

\section{REFERENCES}

1. Andrews, T.E., Houston, W.R., and Bryant, B.L. Adult Learners (A Research Study). (1981).Washington, D.C.: Association of Teacher Educators.

2. Ames, R. and Ames, C. (Eds.). Research on Motivation in Education. (1984). New York: Academic Press.

3. Ausubel, D.P., Novak, J.P., and Hanesian, H. Educational Psychology: A Cognitive View (2 ${ }^{\text {nd }}$ Ed.). (1978). New York: Hold, Rinehart, and Winston.

4. Bellon, J.J., Bellon, E.C., and Handler, J.R. Instructional Improvement: Principles and Processes. (1977). Dubuque, Iowa: Kendall/Hunt.

5. Brookfield, S.D. Understanding and Facilitating Adult Learning,. (1986). San Francisco: Jossey-Bass.

6. Brophy, J. The Role of Rewards and Reinforcements in Early Education Programs, Journal of School Psychology, 10 (No. 3, 1972), 243-251.

7. Christophel, D.M. The Relationship Among Teacher Immediacy Behaviors, Student Motivation, and Learning. Communication Education, 39 (1990), 323-340.

8. Christophel, D.M. and Gorham, J. A Test-Retest Analysis of Student Motivation, Teacher Immediacy, and Perceived Sources of Motivation and Demotivation in College Classes. Communication Education, 44 (1995), 292-306.

9. $\quad$ Cross, K.P. Adults as Learners. (1981). San Francisco: Jossey-Bass.

10. Degree-Granting Postsecondary: Enrollment. National Center for Education Statistics, U.S. Department of Education. (2001). Retrieved on February 25, 2003 from http://nces.ed.gov/pubs2002/digest2001/tables/dt174.asp

11. Erickson, S.C. The Essence of Good Teaching: Helping Students Learn and Remember What They Learn. (1984). San Francisco: Jossey-Bass.

12. Frymier, A.B. The Relationship Among Communication Apprehension, Immediacy and Motivation to Study. Communication Reports, 6 (1993), 8-17.

13. Gorham, J. and Christophel, D.M. Students' Perceptions of Teacher Behaviors as Motivating and Demotivating Factors in College Classes. Communication Quarterly, 40 (1992), 239-252.

14. Gorham, J. and Millette, D.M. A Comparative Analysis of Teacher and Student Perceptions of Sources of Motivation and Demotivation in College Classes. Communication Education, 46 (1997), 245-261.

15. Hunter, M. Motivation Theory for Teachers. (1967). Thousand Oaks: Corwin Press, Inc.

16. Kidd, J.R. How Adults Learn (Revised Ed.). (1973). New York: Association Press.

17. Knowles, M.S. The Modern Practice of Adult Education: From Pedagogy to Andragogy ( $2^{\text {nd }}$ Ed.). (1980). New York: Cambridge.

18. Kolb, D.A. Experiential Learning. (1984). Englewood Cliffs, NJ: Prentice Hall.

19. Maehr, M.L. Confronting Culture With Culture: Creating Optimum Learning Environments For Students of Diverse Sociocultural Backgrounds. (April 13-17, 1998). Paper presented at the Annual Meeting of the American Educational Research Association (San Diego, CA).

20. Mancuso, S. Adult-Centered Practices: Benchmarking Study in Higher Education. Innovative Higher Education, 25 (No.3, 2001), 165-181.

21. Merriam, S.B. and Caffarella, R.S. Learning in Adulthood. (1991). San Francisco: Jossey-Bass.

22. Mouton, J.S. and Blake, R.R. Synergogy: A New Strategy for Education, Training, and Development. (1984). San Francisco: Jossey-Bass.

23. Reid, J.C. Adult Learning. (2000) Retrieved on July 21, 2000 from http://tlc.nlm.nih.gov/resources/p...ions/sourcebook/adultlearning.html 
24. Renchler, R. Student Motivation, School Culture, and Academic Achievement: What School Leaders Can Do. (1992). Eugene, OR: ERIC Clearinghouse on Educational Management.

25. Rinne, C.H. Motivating Students is a Percentages Game. Phi Delta Kappan (April, 1998), 620-628.

26. Russell, I.L. Motivation. (1971). Dubuque, Iowa: William C. Brown Company.

27. Serving Adult Learners in Higher Education: Findings From CAEL's Benchmarking Study. CAEL. (1999). Retrieved on April 11, 2002 from http://www.cael.org

28. Sheehy, G. Passages: Predictable Crises of Adult Life. (1976). New York: Dutton.

29. Tough, A.M. The Assistance Obtained by Adult Self-Teachers. Adult Education, 17 (1966), 30-37.

30. Tough, A.M. The Adult's Learning Projects: A Fresh Approach to Theory and Practice in Adult Learning $\left(2^{\text {nd }}\right.$ Ed.). (1979). Toronto: Ontario Institute for Studies in Education.

31. Wlodkowski, R.J. Motivation and Teaching. (1991). Washington, D.C.: National Education Association. 


\section{NOTES}

